\title{
Development and characterization of microsatellite loci for Ocotea species (Lauraceae) threatened with extinction
}

E.M. Martins ${ }^{1,2}$, G. Martinelli',2, M.P. Arbetman ${ }^{3}$, R.W. Lamont ${ }^{4}$, J.L. Simões-Araújo ${ }^{5}$, D. Powell ${ }^{4}$, M. Ciampi-Guillardi ${ }^{6}$, C. Baldauf ${ }^{7}$, A. Quinet ${ }^{1}$, P. Galisa ${ }^{5,8 \dagger}$ and A. Shapcott ${ }^{4}$

${ }^{1}$ Diretoria de Pesquisa, Instituto de Pesquisas Jardim Botânico do Rio de Janeiro, Rio de Janeiro, RJ, Brasil

${ }^{2}$ Escola Nacional de Botânica Tropical, Rio de Janeiro, RJ, Brasil

${ }^{3}$ Laboratorio Ecotono, Universidad Nacional de Río Negro, Sede Andina, Universidad Nacional del Comahue, Bariloche, Río Negro, Argentina ${ }^{4}$ GeneCology Research Centre, University of the Sunshine Coast, Maroochydore, Queensland, Australia

${ }^{5}$ Centro Nacional de Pesquisa de Agrobiologia, Empresa Brasileira de Pesquisa Agropecuária, Seropédica, RJ, Brasil

${ }^{6}$ Centro de Engenharia Genética e Biologia Molecular, Universidade Estadual de Campinas, Campinas, SP, Brasil

${ }^{7}$ Laboratório de Etnoecologia e Manejo Florestal,

Departamento de Ciência Animal, Universidade Federal Rural do Semi-árido, Mossoró, RN, Brasil

${ }^{8}$ Universidade Federal Rural do Rio de Janeiro, Seropédica, RJ, Brasil

$\dagger$ In memoriam

Corresponding author: E.M. Martins

E-mail: eline@cncflora.net

Genet. Mol. Res. 13 (3): 5138-5142 (2014)

Received May 28, 2013

Accepted October 1, 2013

Published July 7, 2014

DOI http://dx.doi.org/10.4238/2014.July.7.6

ABSTRACT. The Atlantic rainforest species Ocotea catharinensis, Ocotea odorifera, and Ocotea porosa have been extensively harvested 
in the past for timber and oil extraction and are currently listed as threatened due to overexploitation. To investigate the genetic diversity and population structure of these species, we developed 8 polymorphic microsatellite markers for $O$. odorifera from an enriched microsatellite library by using 2 dinucleotide repeats. The microsatellite markers were tested for cross-amplification in $O$. catharinensis and $O$. porosa. The average number of alleles per locus was 10.2 , considering all loci over 2 populations of $O$. odorifera. Observed and expected heterozygosities for $O$. odorifera ranged from 0.39 to 0.93 and 0.41 to 0.92 across populations, respectively. Cross-amplification of all loci was successfully observed in $O$. catharinensis and $O$. porosa except 1 locus that was found to lack polymorphism in O. porosa. Combined probabilities of identity in the studied Ocotea species were very low ranging from $1.0 \times 10^{-24}$ to $7.7 \times 10^{-24}$. The probability of exclusion over all loci estimated for $O$. odorifera indicated a $99.9 \%$ chance of correctly excluding a random nonparent individual. The microsatellite markers described in this study have high information content and will be useful for further investigations on genetic diversity within these species and for subsequent conservation purposes.

Key words: Ocotea catharinensis; Ocotea odorifera; Ocotea porosa; Cross-amplification; Single sequence repeat; Atlantic rainforest

\section{INTRODUCTION}

The genus Ocotea comprises approximately 350 species that are distributed throughout the tropical and subtropical climates. Most species occur in the Americas from Mexico to Argentina, with one species found in the Canary Islands, 7 in Africa, and around 50 in Madagascar (Rohwer, 2000). Due to the value of their timber and essential oils, natural populations of Ocotea catharinensis Mez., Ocotea odorifera (Vellozo) Rohwer, and Ocotea porosa (Nees \& Mart.) Barroso have been heavily exploited from the Atlantic rainforest of Brazil and are consequently experiencing large reductions in population size and area (Araújo, 1948; Reitz et al., 1978; Klein, 1980; Carvalho, 1994). These species are currently classified as being vulnerable to extinction by the IUCN Red List (Varty, 1998; Varty and Guadagnin, 1998a,b) and listed as threatened by the Brazilian list (MMA, 2008). Moreover, large portions of their former habitat have also been modified or destroyed due to urban growth, cattle ranching, and monocultures. Since these factors might have reduced the levels of within-population genetic diversity, potentially increasing the risk of extinction, an investigation to determine how genetic diversity is partitioned within and among populations of these 3 species of Ocotea is important for developing strategies for both in situ and ex situ conservation. Here, we report the development and characterization of 8 polymorphic microsatellite markers for Ocotea odorifera and the transferability of these markers to $O$. catharinensis and $O$. porosa with regard to their application in population genetic assessments and the subsequent formation of efficient conservation strategies for each of the species. 


\section{MATERIAL AND METHODS}

Genomic DNA was extracted from silica gel-dried leaves of 1 individual of $O$. odorifera sampled from a natural population located in Rio de Janeiro, RJ $\left(22^{\circ} 15^{\prime} 5,44^{\circ} 34^{\prime} \mathrm{W}\right)$. A modified CTAB method (Doyle and Doyle, 1987) was used for DNA extraction for initial microsatellite library development. The enriched microsatellite library was developed using the methodology proposed by Billotte et al. (1999) by using the RsaI restriction enzyme (Invitrogen) and 2 dinucleotide repeat sequences. DNA was digested with $R s a \mathrm{I}$, and fragments were linked to RsaI adapters. Microsatellite enrichment was performed using biotin-labeled microsatellite oligonucleotide probes $(\mathrm{CT})_{8}$ and $(\mathrm{GT})_{8}$ with subsequent capture by streptavidin MagneSphere paramagnetic particles (Promega, Fitchburg, WI, USA). Captured DNA was amplified by polymerase chain reaction (PCR) by using primer sequences complementary to the adapters and linked into the pGEM-T vector (Promega). Escherichia coli XL-1 Blue cells (Stratagene, La Jolla, CA, USA) were used for cloning. Forty-eight clones were selected and sequenced on ABI PRISM 377 DNA sequencer (Applied Biosystems, Foster City, CA, USA), of which 20 contained microsatellite motifs suitable for primer design. The program WebSat (Martins et al., 2009) was used to determine the single sequence repeat (SSR) before primer design by using the Primer 3 version 0.4.0 program (Rozen and Skaletsky, 2000). PCR analyses were optimized using DNA from 8 individuals of each of the 3 species obtained from different sampled populations. PCR was performed in a total volume of $12.5 \mu \mathrm{L}$ containing approximately $20 \mathrm{ng}$ template DNA, $1 \mathrm{U}$ MyTaq DNA Polymerase (Bioline), 5 X MyTaq Reaction Buffer (5 mM dNTPs, $15 \mathrm{mM} \mathrm{MgCl}_{2}$, stabilizers, and enhancers; Bioline), and $0.2 \mu \mathrm{M}$ each primer. Cycling conditions were as follows: an initial denaturation at $94^{\circ} \mathrm{C}$ for $5 \mathrm{~min}$, followed by 35 cycles of $94^{\circ} \mathrm{C}$ for $1 \mathrm{~min}$, specific annealing temperature (Table 1) for $1 \mathrm{~min}, 72^{\circ} \mathrm{C}$ for $1 \mathrm{~min}$, and a final extension at $72^{\circ} \mathrm{C}$ for 10 min. Amplification products were checked using agarose gel (2\%) electrophoresis stained with ethidium bromide and compared to a 100-bp size standard (Axygen). Polymorphism analyses were conducted using an AB3500 Genetic Analyzer (Life Technologies Inc., Grand Island, NY, USA) for 2 populations ( $\mathrm{N}=60$ /species) of each of the 3 species.

\begin{tabular}{|c|c|c|c|c|c|}
\hline SSR Locus & Repeat motif & Primer sequence $\left(5^{\prime}-3^{\prime}\right)$ & $\mathrm{Ta}\left({ }^{\circ} \mathrm{C}\right)$ & Allele size (bp) & GenBank accession No. \\
\hline Ood 05 & $(\mathrm{GA})_{7}$ & $\begin{array}{l}\text { F:GACACAGTAATGCTGGGGAAA } \\
\text { R:ACCCTCAACCTCATCATTGC }\end{array}$ & 57 & $246-252$ & KC261494 \\
\hline Ood 07 & $(\mathrm{GA})_{25}$ & $\begin{array}{l}\text { F:TAATGGGTCCCCTGTTTTGA } \\
\text { R:CCCCTTTCTTTCCCTCTCAC }\end{array}$ & 56 & $206-258$ & KC261495 \\
\hline Ood 09 & $(\mathrm{AG})_{14}$ & $\begin{array}{l}\text { F:ATATGCTACTCTTTGGAAGC } \\
\text { R:CTAGTAAAATTGTCCAACGA }\end{array}$ & 56 & $160-186$ & KC261496 \\
\hline Ood 14 & $(\mathrm{TC})_{16}$ & $\begin{array}{l}\text { F:CCTTAAACTTCACCCTCTCC } \\
\text { R:CCAAGTTCAAAAGAGGAAAA }\end{array}$ & 56 & $204-236$ & KC261497 \\
\hline Ood 15 & $(\mathrm{CT})_{17}$ & $\begin{array}{l}\text { F:AACAGAGTGGACTCGAAGAA } \\
\text { R:TATGGAAGTGCCTCTTTCTC }\end{array}$ & 56 & $146-176$ & KC261498 \\
\hline Ood 16 & $(\mathrm{AG})_{17}$ & $\begin{array}{l}\text { F:TCCATTCGGAGAGAAAAATA } \\
\text { R:CTCTAGTGACGGAATGGAAG }\end{array}$ & 56 & $182-226$ & KC261499 \\
\hline Ood 17 & $(\mathrm{CT})_{7} \mathrm{CC}(\mathrm{CT})_{9}$ & $\begin{array}{l}\text { F:AGTAGCTTCACCAACCAAGA } \\
\text { R:TGGCTTGTTTTACTCCCTTA }\end{array}$ & 60 & $212-252$ & KC261500 \\
\hline Ood 20 & $(\mathrm{TC})_{17}$ & $\begin{array}{l}\text { F:TTAGTCTCACCTTCCATTCC } \\
\text { R:TGGACACGAGGTTAGTTTCT }\end{array}$ & 56 & $191-221$ & KC261501 \\
\hline
\end{tabular}

$\mathrm{F}=$ forward $\mathrm{R}=$ reverse $; \mathrm{Ta}=$ optimal annealing temperature.

The presence of null alleles, scoring errors, and large allele dropouts was checked for 
all loci using Microchecker (Van Oosterhout et al., 2004). GenAlEx 6.5 (Peakall and Smouse, 2006) was subsequently used to estimate the mean number of alleles per locus $(A)$ and observed $\left(H_{\mathrm{O}}\right)$ and expected heterozygosity $\left(H_{\mathrm{E}}\right)$ for each locus in each population. Genotypic linkage disequilibrium (LD) and deviations from Hardy-Weinberg equilibrium (HWE) were determined using FSTAT version 2.9.3 (Goudet, 2001). Probability of identity (PI) and probability of exclusion (Q) were also calculated using GenAlEx 6.5.

\section{RESULTS AND DISCUSSION}

Eight polymorphic loci were obtained for Ocotea odorifera, and their characteristics are shown in Table 1. Cross-amplification of all SSR loci was successfully observed in O. catharinensis and $O$. porosa, although there was no polymorphism in the locus Ood16 for the latter species. For $O$. odorifera, the mean number of alleles detected over all loci was 10.2. $H_{\mathrm{E}}$ and $H_{\mathrm{O}}$ ranged from 0.41 to 0.92 and from 0.39 to 0.93 across the populations, respectively. The loci Ood15, Ood16, and Ood 17 in population 2 of $O$. odorifera showed significant departure from HWE after Bonferroni correction. In $O$. catharinensis, the mean number of alleles observed was 8.56, and $H_{\mathrm{E}}$ and $H_{\mathrm{O}}$ ranged from 0.28 to 0.91 and from 0.09 to 0.83 in each of the populations, respectively. In $O$. porosa, the mean number of alleles found across loci was $8.37 ; H_{E}$ ranged from 0.64 to 0.88 and $H_{O}$ from 0.42 to 1.00 across the populations (Table 2). Significant departures from HWE were found in O. catharinensis for loci Ood15, Ood20 (Pop. 1), and Ood17 (Pop. 2). In O. porosa, the loci Ood 05 (Pop. 1) and Ood07 and Ood17 (Pop. 2) deviated significantly from HWE (Table 2). There was no LD detected between pairs of loci for all Ocotea species analyzed.

\begin{tabular}{|c|c|c|c|c|c|c|c|c|c|c|c|c|}
\hline \multirow[t]{2}{*}{ SSR Locus } & \multicolumn{4}{|c|}{ O. odorifera } & \multicolumn{4}{|c|}{ O. catharinensis } & \multicolumn{4}{|c|}{ O. porosa } \\
\hline & Population & $N_{\mathrm{A}}$ & $H_{\mathrm{E}}$ & $H_{\mathrm{o}}$ & Population & $N_{\mathrm{A}}$ & $H_{\mathrm{E}}$ & $H_{\mathrm{o}}$ & Population & $N_{\mathrm{A}}$ & $H_{\mathrm{E}}$ & $H_{\mathrm{o}}$ \\
\hline Ood 05 & \multirow{8}{*}{$\begin{array}{l}\text { Nova Iguaçu/RJ } \\
\text { (pop.1) }\end{array}$} & 4 & 0.58 & 0.43 & \multirow{8}{*}{$\begin{array}{l}\text { Ituporanga/SC } \\
\text { (pop.1) }\end{array}$} & 4 & 0.64 & 0.48 & \multirow{8}{*}{$\begin{array}{l}\text { Mafra/SC } \\
\text { (pop.1) }\end{array}$} & 7 & 0.75 & $0.42^{*}$ \\
\hline Ood 07 & & 17 & 0.91 & 0.79 & & 12 & 0.86 & 0.71 & & 12 & 0.88 & 0.64 \\
\hline Ood 09 & & 11 & 0.89 & 0.93 & & 10 & 0.83 & 0.81 & & 8 & 0.77 & 0.66 \\
\hline Ood 14 & & 10 & 0.86 & 0.79 & & 8 & 0.77 & 0.63 & & 13 & 0.84 & 0.73 \\
\hline Ood 15 & & 10 & 0.83 & 0.70 & & 8 & 0.52 & $0.29^{*}$ & & 6 & 0.71 & 0.88 \\
\hline Ood 16 & & 12 & 0.85 & 0.71 & & 7 & 0.47 & 0.52 & & 1 & - & - \\
\hline Ood 17 & & 11 & 0.88 & 0.78 & & 5 & 0.75 & 0.53 & & 9 & 0.75 & 1.00 \\
\hline \multirow[t]{2}{*}{ Ood 20} & & 13 & 0.91 & 0.73 & & 9 & 0.80 & $0.09 *$ & & 13 & 0.83 & 0.75 \\
\hline & Means \pm SD & $\begin{array}{l}11.00 \\
(1.28)\end{array}$ & $\begin{array}{c}0.84 \\
(0.04)\end{array}$ & $\begin{array}{c}0.73 \\
(0.05)\end{array}$ & Means \pm SD & $\begin{array}{c}7.87 \\
(0.91)\end{array}$ & $\begin{array}{c}0.70 \\
(0.05)\end{array}$ & $\begin{array}{c}0.51 \\
(0.08)\end{array}$ & Means \pm SD & $\begin{array}{c}8.62 \\
(1.45)\end{array}$ & $\begin{array}{c}0.69 \\
(0.10)\end{array}$ & $\begin{array}{c}0.63 \\
(0.11)\end{array}$ \\
\hline Ood 05 & \multirow{8}{*}{$\begin{array}{l}\text { Guaratuba/PR } \\
\text { (pop.2) }\end{array}$} & 3 & 0.41 & 0.50 & \multirow{10}{*}{$\begin{array}{l}\text { Santa Teresa/ES } \\
\text { (pop. 2) }\end{array}$} & 3 & 0.28 & 0.31 & \multirow{10}{*}{$\begin{array}{l}\text { Ponta Grossa/PR } \\
\text { (pop. 2) }\end{array}$} & 9 & 0.75 & 0.56 \\
\hline Ood 07 & & 12 & 0.90 & 0.64 & & 10 & 0.85 & 0.79 & & 9 & 0.84 & $0.48 *$ \\
\hline Ood 09 & & 11 & 0.86 & 0.84 & & 12 & 0.82 & 0.79 & & 13 & 0.86 & 0.68 \\
\hline Ood 14 & & 10 & 0.86 & 0.90 & & 9 & 0.77 & 0.71 & & 14 & 0.82 & 0.79 \\
\hline Ood 15 & & 7 & 0.80 & $0.39^{*}$ & & 15 & 0.91 & 0.79 & & 3 & 0.64 & 0.88 \\
\hline Ood 16 & & 13 & 0.92 & $0.56^{*}$ & & 8 & 0.83 & 0.83 & & 1 & - & - \\
\hline Ood 17 & & 8 & 0.81 & $0.47^{*}$ & & 8 & 0.79 & $0.52^{*}$ & & 5 & 0.74 & $0.46^{*}$ \\
\hline \multirow[t]{3}{*}{ Ood 20} & & 11 & 0.87 & 0.80 & & 9 & 0.75 & 0.68 & & 11 & 0.85 & 0.84 \\
\hline & Means \pm SD & 9.37 & 0.80 & 0.64 & & 9.25 & 0.75 & 0.68 & & 8.12 & 0.69 & 0.58 \\
\hline & & $(1.15)$ & $(0.06)$ & $(0.07)$ & & $(1.22)$ & $(0.07)$ & $(0.06)$ & & (1.66) & $(0.10)$ & $(0.10)$ \\
\hline
\end{tabular}

$N_{\mathrm{A}}=$ number of alleles; $H_{\mathrm{E}}=$ expected heterozygosity; $H_{\mathrm{O}}=$ observed heterozygosity. *Significant departure from HWE after Bonferroni's correction (Rice 1989).

Null alleles were detected for O. odorifera in loci Ood07 and Ood20 (Pop. 1) and 
Ood07, Ood15, Ood16, and Ood17 (Pop. 2); for O. catharinensis, in loci Ood 15 and Ood 20 (Pop. 1) and Ood 17 (Pop. 2); and for O. porosa, in loci Ood 05 and Ood 07 (Pop. 1) and Ood 05, Ood 07, Ood 09, and Ood 17 (Pop. 2). Cumulative probability of identity in Ocotea odorifera for all loci in each population was very low $\left(1.0 \times 10^{-24}\right.$ to $\left.7.7 \times 10^{-24}\right)$, and the probability of exclusion indicated a $99.9 \%$ chance of correctly excluding a random nonparent individual. The highly polymorphic microsatellite markers presented in this study will be appropriate for the analysis of genetic diversity, population structure, and parentage analyses and constitute a useful tool for the conservation of these Ocotea species in the future.

\section{ACKNOWLEDGMENTS}

We would like to thank Centro Nacional de Conservação da Flora (CNCFlora) for financial support and Anete Pereira de Souza and her staff (Universidade Estadual de Campinas, Campinas, SP, Brazil) for the laboratory support to develop the microsatellite markers, the GeneCology Research Centre (University of the Sunshine Coast, Australia) and Instituto de Pesquisas Jardim Botânico do Rio de Janeiro (JBRJ, Rio de Janeiro, RJ, Brazil) for technical assistance and the use of their respective laboratory facilities. The first author is grateful for the sandwich scholarship provided by Coordenação de Aperfeiçoamento de Pessoal de Nível Superior (CAPES).

\section{REFERENCES}

Araújo PAM (1948). Fichas dendrológicas comerciais e industriais brasileiras: Imbuia. Anu. Bras. Econ. Flor. 1: 348-352. Billotte N, Lagoda PJL, Risterucci AM and Baurens FC (1999). Microsatellite-enriched libraries: applied methodology for the development of SSR markers in tropical crops. Fruits 54: 277-288.

Carvalho PER (1994). Espécies Florestais Brasileiras: Recomendações Silviculturais, Potencialidades e Uso da Madeira. EMBRAPA-CNPF, Brasília.

Doyle JJ and Doyle JL (1987). A rapid DNA isolation procedure for a small amount of fresh leaf tissue. Phytochem. Bull. 19: 11-15.

Goudet J (2001). FSTAT, A Program to Estimate and Test Gene Diversities and Fixation Indices (version 2.9.3). Available at [http://www2.unil.ch/popgen/softwares/fstat.htm] Accessed August 2012.

Klein R (1980). Ecologia da Flora e Vegetação do Vale do Itajaí. Sellowia, 389.

Martins WS, Lucas DC, Neves KF and Bertioli DJ (2009). WebSat-a web software for microsatellite marker development. Bioinformation 3: 282-283.

MMA (Ministério do Meio Ambiente) (2008). Instrução Normativa nº.6 de 23/09/2008.

Peakall R and Smouse PE (2006). GenAlEx 6: genetic analysis in Excel. Population genetic software for teaching and research. Mol. Ecol. Notes 6: 288-295.

Reitz R, Klein RM and Reis A (1978). Projeto Madeira de Santa Catarina. Sellowia, 28-30.

Rohwer JG (2000). Toward a phylogenetic classification of the Lauraceae: evidence from matK sequences. Syst. Bot. 25: 60-71.

Rozen S and Skaletsky HJ (2000). Primer3: Bioinformatics Methods and Protocols. In: Methods in Molecular Biology. (Krawetz S and Misener S, eds.). Humana Press, New Jersey, 365-386. Available at [http:// http://frodo.wi.mit.edu/] Accessed August 2012.

Van Oosterhout C, Hutchinson WF, Wills DPM and Shipley P (2004). Micro-Checker: software for identifying and correcting genotyping erros in microsatellite data. Mol. Ecol. Notes 4: 535-538.

Varty N (1998). Ocotea pretiosa. IUCN 2011. IUCN Red List of Threatened Species. Version 2011.2. Available at [www. iucnredlist.org]. Accessed April 17, 2012.

Varty N and Guadagnin DL (1998a). Ocotea catharinensis (1998a). IUCN 2011. IUCN Red List of Threatened Species. Version 2011.2. Available at [www.iucnredlist.org]. Accessed April 17, 2012.

Varty N and Guadagnin DL (1998b). Ocotea porosa (1998b). IUCN 2011. IUCN Red List of Threatened Species. Version 2011.2. Available at [www.iucnredlist.org]. Accessed April 17, 2012. 